\title{
Risky teenager behavior in a vocational high school
}

\author{
Suci Musvita Ayu, Marsiana Wibowo, Liena Sofiana
}

Faculty of Public Health, Universitas Ahmad Dahlan, Indonesia

\section{Article Info}

Article history:

Received Jul 6, 2019

Revised Aug 20, 2019

Accepted Aug 30, 2019

\section{Keywords:}

Risky behavior

Teenager

Vocational high school

\begin{abstract}
Adolescence is a very complex period. Various teen problems haunt when they grow up to become adults. The same teenagers successfully face the challenges of their development so that they are free from a variety of risky behaviors. However, some of them also smoke, consume alcohol, have free sex, commit violence, and use drugs. This research is a qualitative study with a phenomenological approach in which researchers explore and try some risky behaviors in health and factors that influence and how adolescents in vocational high schools end up committing some risky behavior. The results of the study show that teens who do not have risky behavior and who do have some risk behaviors have different understandings related to the impact of these behaviors. People around teenagers influence how teenagers will behave. These influential people can cause teenagers to take risky behavior, such as family problems, get bad examples from parents, family members, peers, and idols. Factors that influence adolescents to end up committing risky behavior are the understanding of the negative effects of risk behavior. The various causes of influential people include parents, peers, religious leaders, idols, perceived benefits, self-control, and intention. The internal and external factors of adolescents determine whether the teenager will do or not risky behavior. Strong collaboration between internal and external factors shapes behavior which is not risky in adolescents, and vice versa.
\end{abstract}

Copyright $@ 2019$ Institute of Advanced Engineering and Science. All rights reserved.

\section{Corresponding Author:}

Suci Musvita Ayu,

Department of Public Health, Faculty of Public Health,

Universitas Ahmad Dahlan,

Prof. Dr. Soepomo Street, Janturan, Yogyakarta (55164), Indonesia.

Email: suci.ayu@ikm.uad.ac.id

\section{INTRODUCTION}

In Indonesia, one-fifth of the population is teenagers who have the opportunity to commit risky behavior without being aware of the long-term consequences of the behavior. They adopt risky behaviors through unhealthy relationships and undirected information. Progress or modernization turns out to have two sides that can be beneficial and/or also detrimental, especially the problem of progress in the field of information technology. The era of globalization and openness of infonnation, such as the internet, makes all forms of information very easy to obtain, even from those who are in small cities [1].

In adolescence, biological, psychological and social changes occur rapidly. This requires changes in the behavior of adolescents to adjust to their current conditions. In some adolescents, this adjustment process can take place without significant problems because they succeed in recognizing their identity and getting sufficient social support. Both play a role in adolescent adjustment. But some other teenagers can experience adjustment problems. Difficulties in adolescent adjustment are usually preceded by the emergence of risky behaviors causing adolescent psychosocial problems both on a personal and social level. Adolescent risky behavior makes them often labeled as troubled teenagers and eventually they are treated negatively from their social environment. Teenage risky behavior is a form of behavior that can endanger the health and well-being of adolescents, even some forms of risky behavior can harm others [2]. 
Risky behavior arises because it is influenced by risk factors (risk factors) that come from within adolescents (level of the individual), from the family (level of the family) and from outside the family (extrafamilial relations). Factors derived from adolescents (level of the individual) are low achievement motivation (low achievement motivation) and low self-esteem (low self esteem), factors of the family (level of the family) are very strict parents (high strictness) and low support and extrafamilial relations are deviant peers and extreme peer orientation [3].

In Indonesia, adolescents (15-24 years) who had premarital sexual relations in urban areas in 2007 amounted to $0.9 \%$ (female) and $6.4 \%$ (male), while in rural areas, there were $1.7 \%$ women and $6,3 \%$ men. This factincreased in 2012, amounting to $0.9 \%$ women and $8.7 \%$ of urban men and $1.0 \%$ of women and $7.8 \%$ of rural men had premarital sexual relations [4].

Preliminary studies conducted showed that $89.4 \%$ of adolescents had carried out risky behaviors for their health, such as smoking, drinking alcohol, premarital sex, dating violence, and consuming drugs. Some of the respondents have good self-confidence, while others have less self-confidence in behavior. In line with these results, some respondents also stated that the role of peers is very important in shaping their behavior, while others do not. Peers have the greatest relationship strength to risky health behaviors. Exposure to information sources about smoking, drinking alcohol, pre-marital sex, dating violence, and consuming drugs with a high category amounted to $75.7 \%$ of respondents.

\section{RESEARCH METHOD}

This research is qualitative research with phenomenological approach. Phenomenological studies focus on one's subjective experience and interpretation of the world. The results of this study illustrate the structure of one's experience that they display with awareness, without theory, subtraction, or assumptions from other scientific disciplines [5]. The research subjects consisted of the main subjects, namely vocational high school students who had risky behavior (two students) and vocational high school students who did not have risky behavior (two students). The instrument in this qualitative research is the researchers themselves. While the research tool used is the guideline for in-depth interview focus group discussion, log book, and the log book is used as a tool to record information obtained during the research process, and an audio recorder is used to record the interview process. The data collection techniques used were interviews and focus group discussion (FGD).

\section{RESULTS AND DISCUSSION}

Data collection had been carried out in Yogyakarta by involving students from a Vocational School in Yogayakarta, Indonesia. Characteristics of informants based on gender, maternal education level and father's education level are showed in Table 1.

Based on the results of Table 1 data, it was found that the informants obtained in this study consisted of two people who did not carry out risky behavior and two people who did risky behavior. Informants have been educated in the Third-Class Vocational School (VOC) (XII). The sex of the informants were women with an average age of 17 amounting to three $(75 \%)$ and 18 years amounting to one person (25\%). The parental education background is divided into four high-level backgrounds in the mother's category. While the education of fathers in the low category is one person and higher education is three people. Indicators of risky teenager behaviour are showed in Table 2.

Table 1. Frequency distribution of characteristics of informants based on gender, age, maternal education level and father's education level

\begin{tabular}{|c|c|c|c|}
\hline \multicolumn{2}{|c|}{ Variable } & \multirow{2}{*}{$\frac{\text { Frequency }}{3}$} & \multirow{2}{*}{$\frac{\text { Percentage }(\%)}{75}$} \\
\hline & 17 years & & \\
\hline Age & 18 years & 1 & 25 \\
\hline \multirow{2}{*}{ Gender } & Male & 0 & 0 \\
\hline & Female & 4 & 100 \\
\hline \multirow{2}{*}{ Maternal Education } & Low (PS-JHS) & 0 & 0 \\
\hline & High (SHS-College) & 4 & 100 \\
\hline \multirow{2}{*}{ Paternal Education } & Low & 1 & 25 \\
\hline & High & 3 & 75 \\
\hline \multirow{2}{*}{ Behavior } & Risky & 2 & 50 \\
\hline & Not Risky & 2 & 50 \\
\hline
\end{tabular}


Table 2. Analysis result of indicator of risky teenager behavior

\begin{tabular}{|c|c|c|c|c|c|c|c|}
\hline No & Indicator & Smoking/Cigarette & Alcohol & $\begin{array}{l}\text { Risky } \\
\text { Drugs }\end{array}$ & Vilolence & Free Sex & Not risky \\
\hline 1 & $\begin{array}{l}\text { The } \\
\text { understanding } \\
\text { of risky } \\
\text { behavior }\end{array}$ & poor & poor & poor & poor & poor & $\begin{array}{l}\text { Good } \\
\text { (understand } \\
\text { the negative } \\
\text { effect) }\end{array}$ \\
\hline 2 & Causes & $\begin{array}{l}\text { a. Family history } \\
\text { b. Trying } \\
\text { c. Bullying } \\
\text { d. Environment } \\
\text { e. Instagram } \\
\text { celebrities }\end{array}$ & $\begin{array}{l}\text { a. Trying } \\
\text { b. Environment } \\
\text { c. Friends }\end{array}$ & $\begin{array}{l}\text { a. Trying } \\
\text { b. Environme } \\
\text { nt } \\
\text { c. Friends }\end{array}$ & $\begin{array}{l}\text { a. Family } \\
\quad \text { history } \\
\text { b. Trying } \\
\text { c. Bullying } \\
\text { d. Environment } \\
\text { e. Media }\end{array}$ & $\begin{array}{l}\text { a. Trying } \\
\text { b. Environment } \\
\text { c. Instagram } \\
\quad \text { celebrities }\end{array}$ & $\begin{array}{l}\text { There is an } \\
\text { influence } \\
\text { from the } \\
\text { close ones }\end{array}$ \\
\hline 3 & Influencers & $\begin{array}{l}\text { Internal: parents } \\
\text { External: peers and } \\
\text { idol }\end{array}$ & $\begin{array}{l}\text { Internal: } \\
\text { parents } \\
\text { External: } \\
\text { peers and idol }\end{array}$ & $\begin{array}{l}\text { Internal: } \\
\text { parents } \\
\text { External: } \\
\text { peers and } \\
\text { idol }\end{array}$ & $\begin{array}{l}\text { Internal: } \\
\text { parents } \\
\text { External: } \\
\text { peers and idol }\end{array}$ & $\begin{array}{l}\text { Internal: parents } \\
\text { External: peers } \\
\text { and idol }\end{array}$ & $\begin{array}{l}\text { Internal: } \\
\text { parents } \\
\text { External: } \\
\text { Ustad/ustadz } \\
\text { ah, peers and } \\
\text { idols }\end{array}$ \\
\hline 5 & $\begin{array}{l}\text { Previed } \\
\text { Control }\end{array}$ & $\mathrm{Bad}$ & $\mathrm{Bad}$ & $\mathrm{Bad}$ & $\mathrm{Bad}$ & $\mathrm{Bad}$ & Good \\
\hline 6 & $\begin{array}{l}\text { Intention to } \\
\text { commit risky } \\
\text { behavior }\end{array}$ & There is one(s). & $\begin{array}{l}\text { There is } \\
\text { one(s). }\end{array}$ & $\begin{array}{l}\text { There is } \\
\text { one(s). }\end{array}$ & $\begin{array}{l}\text { There is } \\
\text { one(s). }\end{array}$ & There is one(s). & none \\
\hline
\end{tabular}

Based on the results of Table 2 data, it was found that informants who have risky behavior they have poor understanding of risky behavior, this is different from informants who do not risky behavior where they understand the negative effect of risky behavior. Causes they do risky behavior are trying, environment, friend and social media, while for informants who do not risky behavior cause they have an influences from the close ones. Factors that influence the occurrence do or do not risky behavior is parents from internal factor and from external factor are peers and idol. They do the risky behavior because they think that doing so will benefits are considered as problem solving and showing youth identity.

\subsection{Teenagers phenomena in Yogyakarta}

The interviews were carried out to informants who were not at risk and at risk. Informants came from students of one of the vocational high schools in Yogyakarta who stated that there are many factors influencing adolescent behavior such as smoking, bullying, disrespectful behavior towards teachers, hanging out at midnight, watching indecent videos, consuming alcohol, consuming drugs and premarital sex. This is supported by interviews with informants who are not at risk:

“...Why do you still smoke when you know it's dangerous?” (AM1, 17 years).

“...I don't like if there is someone bullying me, if I stay quiet, I will definitely be bullied” (AM1, 17 years.).

“... They are going out and one of them watch blue movies.” (AM1, 17 years).

“... They talk to teachers like talking to their friends. They often go out late night, smoke, and drink alcohol. Most of them are already married" (AM1, 17 years).

“...Smoking is actually not good, they are not only active smoker but also passive smoker" (IK2, 18 years).

“...I have been told, that after drinking, they will fly.” (AM1, 17 years).

The results of interviews with informants who did not do risky behavior showed that informants never did things that were risky behavior. It is because they realize that there is a negative impact from this behavior. The response of informants who commit risky behavior:

“...I have tried smoking and it doesn't feel good.” (T4, 17 years).

“...I have ever bullied but not with violence” (DE3, 17 years).

"...I am curious because my friends told me that when you are drinking, I will forget all my problems" (T4, 17 years). 
“...When I was in junior high school, I have ever taken drugs. The pill is small like a family planning pills, sometimes antimo combined with BigCola. The drugs are out in a plastic and after that we'll go fly” (DE, 317 years).

“...Most of my classmates have ever done free sex, and I only kiss” (T4, 17 years).

“...I'm curious to try consuming alcohol, but I still hesitate to try” (T4, 17 years).

Based on the results of interviews with risky informants, it was found that the informants did this based on resentment towards ridicule from friends so that there was resistance from the informants to defend themselves, besides because of the curiosity that they wanted to experiment, and often did to eliminate problems that are being experienced.

\subsection{Things that affect teenagers to behave}

Based on previous research, non-risky and risky behavior are influenced by several things, namely schoolmates, parents and personal problems. The results of interviews with informants who did not carry out risky behavior were supported by some statements:

“...I am not interested doing those things because I need to maintain my image” (IK2, 18 years).

"...I want to avoid friends who are like that because my parents said so" (AM1, 17 years).

The interviews with informants who were not at-risk show that they were not interested and wanted to avoid negative things, for reasons of counseling parents, teachers, and wanting to maintain a good image for themselves. The response of informants who did risky behavior:

“...I smoke, drink, free sex because I need to have fun and forget my problems. It is because I have a family problem, they play favorite” (T4, 17 years).

“...I feel lonely so I just have a relationship. My big sister had runaway from home because of family problems and ran with her boyfriend" (T4, 17 years).

\subsection{The benefits of not committing risky behavior}

The results of the interviews that have been made to the informants show that the benefits of not risky behavior are to make it more focused, calmer and more able to maintain a good name, both for yourself and family. This is supported by the following statements.

"...My mind is fresher and I become more focus on things" (AM1, 17 years).

“...It is because of my parents' words for not involving on bad behavior, maintaining my image and they said it's better to do positive activities" (IK2, 18 years).

\subsection{Environmental opinions regarding risk behaviour}

The results of interviews that have been conducted are from the ones done to informants who are not at risk and who are at risk. The informants came from several students at one of the vocational high schools in Yogyakarta. Opinions expressed include:

“... Risky behavior can actually get rid of problems, such as smoking and going out” (T4, 17 years).

“... Nothing special, I did it often and people also see it” (DE3, 17 years).

"...It is more fun to hang out with friends than with family" (IK2, 18 years).

“...In the neighborhood, my neighbors mostly don't know because most of them are children” (AM1, 17 years).

“...Parents only told me not to do bad things" (IK2, 18 years)

\subsection{People influencing}

Based on the results of the interviews, informants' behavior was not risky and risky. The informant revealed that there was an influence from external parties, especially parents related to maintaining relationships, and from religious leaders with frequent listening or watching religious services both directly and online. As for the risk informants, they revealed that they got influence from Celebrity Instagram (celebgram). The statements are presented as follows:

“...I like to hear Ust. Hanan Attaki’s tausiyah)” (AM1, 17 y.o.).

“...I was inspired by my mom because of her patient and simplicity” (IK2, 18 years)

Response:

“...I am influenced by other people and selebgram. They are in a relationship for about five years” (T4, 17 years).

“...My parents told me to maintain my image and be patient in facing problems calmly” (DE3, 17 years). 
Based on the results of the study, it is known that adolescents who do not do risky behavior have a good understanding of the effects of risky behavior. Risk behaviors such as smoking, premarital sex, dating violence, drinking alcohol, and consuming illegal drugs have a negative impact on health, both physical and mental health. The level of knowledge about cigarettes is inversely proportional to smoking behavior.

Factors that significantly influence the risky behavior of adolescents based on SKRI 2007 data are knowledge, attitudes, gender, age, education, economic status, access to information media, communication with parents, and the presence of risky behavior friends. The most dominant variable associated with risky behavior in adolescents is gender. Teenage boys have 30 times more chance to smoke, 10 times more to drink alcohol, 20 times more for drug abuse, and 5 times more for pre-marital sex when compared to teenage girls [6].

According to the Indonesian Reproductive Health Survey (SKRI) in 2007, it was found that 55.2\% of teenagers in Indonesia carry out risky behaviors (smoking, drinking alcohol, premarital sex, and drug abuse). The causes of adolescent risk behavior consist of four causes, the existence of family problems, getting a bad role model from family members, getting a bad role model from celebrities (Instagram celebrities), bullying, and unfavorable coping which consider risky behavior as a solution to problems. In smoking behavior, smokers and non-smokers have different knowledge [7]. There are $1.4 \%$ of middle and high school teens who experience abuse every day. Sexual harassment or jokes are the second most common type of abuse that is often experienced by middle and high school teens. A total of $4.68 \%$ had been beaten, slapped or intentionally physically hurt by his girlfriend. In boys it is $6.95 \%$ and $2.54 \%$ in girls [8].

People who influence adolescents in determining whether their behavior are at risk consist of two sources, namely internal and external. Parents have a strong influence in determining the behavior of their children. The tobacco consumption behavior of parents affects significantly the smoking behavior of adolescents [9]. The choice of people from the external environment as influential people greatly determines adolescent behavior. For adolescents who are not at risk, Ustadz or religious leaders are one of the role models in behaving. There is a significant relationship between religiosity and juvenile delinquency. The higher the level of adolescent religiosity, the lower the tendency of juvenile delinquency [10]. Commitment to religious values prevents behaviour adversely affects health and promotes perspective and behaviour healthy ones [11]. Religiosity has a greater role in the acquisition of experience attitudes and positive emotions someone compared demographic characteristics [12]. They also choose idols who behave exemplary. Meanwhile, adolescents who are at risk, they have friends who behave in the same way, namely smoking, premarital sex, consumption of drugs, even drinking alcohol and violence.

School friends have no more significant influence than friends in the home environment and friends other than in school and home environment towards adolescent smoking behaviour [13]. In alcohol consumption, peers have a strong influence on influencing alcohol drinking behaviour [14]. They also get access to public figures from programs that are not good. The program conducts risky behavior so that the adolescent adheres to / follows. Peers, environment, and education level significantly influence the smoking behaviour [15]. The signs are caused by use alcohol (alcohol) generally will cause courage to lead to abusive behavior, short-tempered, irritable and act brutally [16].

Adolescents who behave not at risk and are not at risk have a different way of looking at the benefits of their behavior. For teens who behave not at risk, they argue that risk behavior will not provide any benefits. To maintain good behavior, adolescents behave not at risk of feeling more focused in doing their activities, calmer, and able to maintain family dignity. While for adolescents at risk, they use risky behavior to solve problems they face. That is, smokers assume that smoking can be used as a way to treat themselves from feelings of anxiety and stress due to the problem. But not as expected, smoking actually increases anxiety and tension. The feeling of relaxation is temporary and immediately asks for it again by smoking again. Smoking is not an effective way to overcome mental health problems [17]. Smoking can significantly affect mental health [18].

Based on this description, adolescents who do not risk behavior do not have the intention to do any of these risk behaviors. They have good control to stay away from, avoid, and even obey not to do risky actions consistently. Self-control and smoking behavior have a negative relationship, meaning that the stronger the self control, the less likely the possibility of smoking [10, 19].

There is a significant relationship between self control and juvenile delinquency. Good self control is what can bring positive consequences [10]. Adolescent self control of smoking behavior is also influenced by teenagers' perceptions of the type of parenting parents. Adolescents who perceive parenting patterns are not permissive have a higher level of self-control of smoking behavior than adolescents who perceive permissive parenting [20].

There needs to be strengthening in the distribution of information to adolescents at the school level. This program empowers adolescents to reject smoking laughter and peer pressure [21]. School-based health and cigarette intervention programs have a positive impact on increasing knowledge among Indonesian 
adolescents [22]. There is a need for denormalization of cigarette consumption and systemic impact interventions to control adolescent smoking behavior [13]. Adolescents need norm education as early as possible [23, 24]. Moral education and honesty can shape the character of a child at future [25].

\section{CONCLUSION}

The internal and external factors of adolescents determine whether the teenager will do the risky behavior. A strong collaboration between internal and external factors shapes behavior which is not risky from adolescents, and vice versa.

\section{REFERENCES}

[1] D. Rokhmah, "Parenting and formation of sexual behavior risk for HIV / AIDS in transvestites," J. Kesehat. Masy., vol. 11(1), pp. 125-134, 2015.

[2] R. Margaretha, "The relationship between emotional violence in children and the tendency of juvenile delinquency," Junal Psikologis Klin. dan Kesehat. Ment., vol. 1(2), pp. 1-9, 2012.

[3] M. S. Dekovic, "Risk and protective factors in the development of problem behavior during adolescence," J. Youth Adolesc., vol. 28(6), pp. 667-685, 1999.

[4] BPS, BKKBN, Kemenkes, and ICF International, Indonesia Demographic and Jakarta: BPS, BKKBN, Kemenkes dan ICF International. Jakarta: BPS, BKKBN, Kemenkes, ICF International, 2013.

[5] Denzin and Lincoln, Handbook of Qualitative Research. Yogyakarta: Pustaka Pelajar, 2009.

[6] H. Lestari, "Young adults risk behavior by Indonesia young adult reproductive health survey," J. Kesehat. Reproduksi, vol. 1(3), pp. 136-144, 2007.

[7] X. Xu, D. Yin, P. Leung, B. Li, P. Wang, and Y. Zhao, "Smoking-related knowledge, attitude, social pressure, and environmental constraints among new undergraduates in," Int. J. Environ. Res. Public Health, vol. 12(2), pp. 895909, 2015.

[8] N. Kusumawardani et al., Health Risk Behavior in Middle and High Schools in Indonesia. Jakarta: Badan Litbangkes Kementerian RI, 2015.

[9] S. E.-T. El-Amin, B. I. Nwaru, I. Ginawi, P. Pisani, and M. Hakama, "The role of parents, friends and teachers in adolescents' cigarette smoking and tombak dipping In sudan," BMJ J., vol. 20(2), pp. 94-99, 2011.

[10] E. Aviyah and M. Farid, "Religiosity, self control and juvenile delinquency," Pers. J. Psikol. Indones., vol. 3(2), pp. 126-129, 2014.

[11] A. M. Abdel-khalek and D. Lester, "The association between religiosity, generalized self-ef fi cacy , mental health , and happiness in Arab college students," Pers. Individ. Dif., vol. 109, pp. 12-16, 2017.

[12] N. M. Lestari, S. Psikologi, F. Kedokteran, and U. Syiah, "Effects of Gender, age, and religiosity on adolescent mental health," Philanthr. J. Psychol., vol. 1(2), pp. 85-102, 2017.

[13] A. Liem, "The influence of mass media, family, and friends on teenage smoking behavior in Yogyakarta," Makara Hubs-Asia, vol. 18(10, pp. 41-52, 2014.

[14] C. Jalling, T. H. Elgán, A. Tengström, and A. Birgegård, "Gender-specific predictors of at-risk adolescents , hazardous alcohol use-a cohort study," Subst. Abuse Treat. Prev. Policy, vol. 12(23), pp. 1-10, 2017.

[15] M. Pakidi and S. Widiati, "Factors affecting young women smoking behavior in Taman Bungkul Surabaya," $J$. Promkes, vol. 3(1), pp. 25-37, 2015.

[16] P. L. P. Rori, "Effects of the use of liquor on teen life in Kali Village, Pineleng District, Minahasa Regency," Holistik J. Soc. Cult., vol. 8(16), pp. 1-12, 2015.

[17] ASH, "Smoking and mental health. action on smoking and health," 2013.

[18] R. Waziry, M. Jawad, R. A. Ballout, M. Al Akel, and E. A. Akl, "The effects of waterpipe tobacco smoking on health outcomes : An updated systematic review and meta-analysis," Int. J. Epidemiol., vol. 46(1), pp. 32-43, 2017.

[19] G. C. Runtukahu, J. Sinolungan, and H. Opod, "Relationships between self-control with smoking behaviors In SMK 1 Bitung," J. e-Biomedik, vol. 3(1), pp. 84-92, 2015.

[20] R. Wulaningsih, "Relationship between parental parenting perceptions and adolescent self control on smoking behavior in Islamic Boarding Schools," J. Psikol. Klin. dan Kesehat. Ment., vol. 4(4), pp. 119-126, 2015.

[21] M. Dahlui, N. K. Jahan, H. A. Majid, M. Y. Jalaludin, L. Murray, and M. Cantwell, "Risk and protective factors for cigarette use in Young Adolescents in a School Setting: What could be done better?," PLoS One, vol. June(11), pp. $1-12,2015$.

[22] T. Tahlil, R. J. Woodman, J. Coveney, and P. R. Ward, "The impact of education programs on smoking prevention: a randomized controlled trial among 11 to 14 year olds in Aceh, Indonesia," BMC Public Health, vol. 13(367), pp. $1-11,2013$.

[23] H. T. Greene and shaun L. Gabbidon, Encyclopedia of Race and Crime. SAGE Publication, 2009.

[24] T. KA, S. TN, and F. AD, "Longitudinal relationships between individual and class norms supporting dating violence and perpetration of dating violence," $j$ Youth Adolesc, vol. 44(3), pp. 745-760, 2015.

[25] D. Satya, Y. Agustin, N. W. Suarmini, and S. Prabowo, "the role of the family is very important in mental education, children's character and children's character building," J. Sos. Hum., vol. 8(1), pp. 46-54, 2015. 